\title{
The China-India Challenge: A Comparison Of Causes And Effects Of Global Warming
}

Betty J. Diener, Barry University, USA

William P. Frank, Barry University, USA

\begin{abstract}
It is likely that the future environment of our globe depends on the actions taken by China and India as they develop into two of the three largest economies in the world over the next twenty-five years. The global warming problem alone will be dominated by the total greenhouse gas emissions from these two countries. This article summarizes the economic growth of these two countries, the resulting increasing environmental problems, the trends and impacts of increased energy consumption, the trends and impacts of greenhouse gas emissions, and the potential for reducing these impacts, should the two countries have the will to do so.
\end{abstract}

Keywords: China and India, economic growth, energy demand, energy sources, global warming

\section{INTRODUCTION: THE ECONOMIES AND ENVIRONMENTS}



he impact of India and China starts with their sheer size--the two together currently account for 2.5 billion people, or $40 \%$ of the world's population. Their economies, even though one is currently predominant in global manufacturing and the other in global services, are both fast growing in all areas, with China expected to become the second largest economy in the world by 2016 and India expected to become the third largest by 2034 .

Both countries have been fast growing economically. During 2004-2006, China's GDP growth was 10\% and India's was $8 \%$. Then, in 2007, while the global economy grew only $5 \%$, China's economy grew by $11.5 \%$ and India's grew by $8 \%$. While China's per capita growth rate was, for a number of years, twice as rapid as India's, this gap has narrowed in recent years as India's growth has accelerated. China, since 1978, has gradually changed its economic structures, from its historical origins in state ownership of large state owned enterprises with access to cheap labor and long-term capital, to a strong manufacturing base with private ownership and a new political environment of "market capitalism". India, in the early 90's, implemented reforms in foreign trade and investment, exchange rates, and industrial policies that facilitated its transition to a market-based economy and more rapid growth. The GDP growth rates of both countries are expected by many to exceed $10 \%$ annually going forward.

Formerly thought of as off-shore outsourced manufacturing sites or distant service centers of U.S. parent companies, China and India are now home to increasingly innovative and important global companies such as Lenovo, Qingdao, Haier, Huawei and Handan Iron \& Steel in China and Tata, Infosys, Wipro, ICICI Bank, and Ranbaxy Pharmaceuticals in India. As China and India are rapidly growing and are increasing their impact on political, economic, and social conditions around the world, they are also having a major impact on the global environment. A recent study quoting Yale-Columbia's Environmental Performance Index ranked China at \#113 and India at \#120 in terms of polluted environments.

The examples of the environmental problems in both countries are both numerous and similar. More than $75 \%$ of the water in China's urban rivers are unsuitable for drinking or fishing. In India, the rivers are described as toxic cesspools, with declining fish populations near large coastal cities like Mumbai and Calcutta. One in four Indians has no access to safe water and $90 \%$ of the water resources are polluted. Groundwater levels in both countries are falling, with much of the groundwater also polluted. 
Desert covers one-quarter of China's land, with rampant deforestation and soil degradation. India is similar, with $90 \%$ of the wildlife habitats lost to agricultural destruction and deforestation by the mid- 1990's, and the loss of 25 billion tons of topsoil from 1995 and 2000.

Air pollution in both countries is alleged to have caused millions of deaths, with highly toxic air in India's 28 largest cities, particularly in the slum areas where $35 \%$ of the urban residents live. China has six of the ten most polluted cities in the world. Acid rain affects more than one-third of China's land, including its farmland, before drifting eastward over Japan.

\section{ENERGY DEMAND}

With rapid economic growth in economic development has come increased use of energy. China and India account for $68 \%$ of the electricity generated in the developing countries of Asia.

China's GDP and energy consumption, for the past four years, have increased $11 \%$ a year. In addition to its growth in energy consumption, China's usage is also inefficient. China uses three times as much energy as the US in order to produce \$1 of goods. During this period, India's GDP has grown 9\% a year and its energy demand by $4 \%$. India's industry is said to be more efficient than China's because industry historically has had to pay a premium for electricity in order to subsidize agriculture. Thus, they have invested in more cost efficient energy generation. One result is that India has become one of the world's lowest cost producers of aluminum and steel.

China is currently the world's second-largest energy market and, while hoping to quadruple its economic activity, is anticipating doubling the amount of energy used annually. China consumed 1.742 mtoe (million tons of oil equivalent) in 2005, and expects this to increase to 3819 mtoe in 2025. In terms of gigawats of electric demand, China expects to increase by 2600 gigawats by 2050 --the same as adding four 300-megawat power plants each week for 45 years!

The enormous growth in energy demand since 2004 has also already created energy shortages in both countries, at a time when there is a potential increase in demand among the many homes in both countries that are currently without access to electricity that might become electrified in the future. This was true of over 78 million homes in India (covering half its population) and 30 million homes in China in 2005. India 's demand for energy rose by 2.3\% per year during 2009-2005 and now is at the level of Japan, at 537 mtoe. This demand is expected to increase by at least $4.7 \%$ per year in 2005-2015, fueled by development in the infrastructure and transport sectors. Other forecasters predict the possibility of long term growth of $8 \% / y$ ear, requiring a boost of power generating capacity 6-fold, with emissions expected to increase 4-fold.

The most alarming aspect of this growth in energy demands by the two countries, is that the growth would require a level of energy supplies literally beyond the world's energy resources, if no steps are effectively taken to curb energy intensity. It would also outstrip the planet's absorptive capacity, with a catastrophic effect on climate change. If the per capita oil demand in China and India were to equal current US per capita levels, this combination would be twice the level of current world oil demand, depleting proven oil reserves in only 15 years.

\section{ENERGY SOURCES}

One similarity in the source of energy for the two countries is that, together, they consume $45 \%$ of the world's coal, a natural source of energy for them since they have the world's $3^{\text {rd }}$ and $4^{\text {th }}$ largest coal reserves. China's is a high sulphur coal, thus its emission reduction efforts are focusing on $\mathrm{SO} 2$ removal from the coal in order to reduce emissions. India's coal is lower in sulphur and higher in ash; it focuses on controlling particulates and disposal of ash. Because of the pollution from coal, each is trying to diversify its energy sources beyond coal. At the same time, each is also trying to reduce its dependence on oil because of price fluctuations. Imported oil is only $10 \%$ of China's energy sources (coal is $70 \%$ ), but is necessary for its transportation needs. China's goal was to increase its use of renewable energy fuels from $8.5 \%$ in 2003 to $10 \%$ by 2012. This level decreased to $7 \%$ in 2005 , however, because of the overall increase in usage was focused on non-renewables. India's use of renewable energy fuels was $4.3 \%$ in 2003 . At the same time, India was the fourth biggest producer of wind power in the world and its 
Suzion Energy is one of the five biggest wind turbine manufacturers in the world. China's Suntech is the world's third largest manufacturer of solar cells. The two countries are also considering jointly developing their nuclear power capacities. Nevertheless, both countries continue to be increasingly dependent on coal.

\section{ENERGY IMPACTS}

Increased_energy usage, particularly when using nonrenewable sources like coal, leads to increased emissions of $\mathrm{CO} 2, \mathrm{CO}, \mathrm{SO} 2, \mathrm{NOx}$, and Mercury, leading to acid rain, air pollution, and negative health effects, not including mine accidents and land degradation. The biggest concern world-wide is with the $\mathrm{CO} 2$ and greenhouse gas emissions that will lead to further global warming. The power sectors alone in China and India contribute $42 \%$ of carbon emissions in China and 52\% of those in India.

China is almost certainly already the number one emitter of greenhouse gasses. It has more than doubled its emissions level since 1985. And, by 2015, China will again double its use of energy, while India will increase its energy use by $50 \%$. India is now the $15^{\text {th }}$ largest carbon emitter in the world. It is estimated that India's emissions will increase by $70 \%$ by 2025 . Based on their joint reliance on coal, the two countries will account for $40 \%$ of the global CO2 emissions by 2025 (China accounting for 25\% and India for 15\%).

\section{IMPACTS OF GLOBAL WARMING}

The impacts of global warming include severe weather events, massive flooding, and severe droughts throughout the world. Examples of the impacts are plentiful in China and India. Glaciers, for example, support 1.3 billion people in India and China. Glaciers on the Tibetan Plateau in the Himalayas are melting, with estimates that they will disappear in 20-30 years. On the Chinese side they have shrunk by $25 \%$ from 1950-2050. One Indian glacier has shrunk by half its length in the last decade.

The impacts on the water supplies in both China and India will be severe. In China the impacts on the water supplies have already begun to be noted in the Yangtze and Yellow rivers. Recently the Yangtze River was very low with the area experiencing the worst drought since 1877. In India, the impact will be on the Indus, Ganges and Brahmaputra rivers. At the other end of the rivers, at the sea, sea levels are expected to increase, resulting in flooding by 2030 of the deltas of the Yangtze, Yellow and Pearl rivers, currently major manufacturing and export areas of China. Coastal flooding from melting glaciers could submerge the commercial centers of Shanghai and Shenzhen. The concern in India is that Bangladesh will disappear, driving 35 million refugees to India. And, there should there be a four degree centrigrade temperature increase by 2080, it could cause a $5 \%-10 \%$ reduction in agricultural output in China and a 30-40\% reduction in India, thus severely threatening food security in the region.

\section{SOLUTIONS}

The nations of the world are attempting to find ways of getting international agreements on global warming and reductions in $\mathrm{CO} 2$ emissions. Certainly, given the impacts noted above, both India and China should be especially concerned about global warming. And, given the level of their contributions to the problem, each would become a major factor in whether or not global warming can be contained.

The first global attempt to control emissions resulted in the Kyoto agreement of February 16, 2005. At that time, industrial countries agreed to limit per capita carbon emissions by an average of $5 \%$ by 2012 . Developing countries such as China, however, were not assigned the same reductions in order to allow it to continue to develop its economy. The United States Senate refused to ratify the agreement, arguing that it would not agree to any reductions unless all countries were included in the agreement. Since 1990 US emissions have increased by $16.7 \%$. Now, since his election, President Barack Obama has called for Congress to establish limits for greenhouse gases that would reduce US emissions to 1990 levels by 2020 and cut them another $80 \%$ by 2050. This is especially significant since negotiations have begun again, hopefully to be concluded next year in Copenhagen, Denmark, resulting in a new world-wide treaty to replace the one from Kyoto. 
In a conference in Poznan, Poland that is leading up to the Copenhagen meeting, the European Union recently agreed on a plan to reduce greenhouse emissions $20 \%$ and to ensure by 2020 that $20 \%$ of energy comes from wind, sun and renewable resources. The plan increased the amount of emissions that Europeans could offset by sponsoring green projects in developing countries. (Some, however, predicted that this would then result in reductions of only $4 \%$ in Europe itself, not $20 \%$ ).

\section{REDUCTIONS IN EMISSIONS}

China and India are just beginning to awaken to the impacts of being huge greenhouse gas emitters. Neither China nor India are setting emissions caps. China's per capita use of energy is only $1 / 8$ that of the United States. China's solution instead is to try to reduce their energy intensity. India's response, on the other hand, is considered to be "haphazard" and "resistant". India, for example, has insisted on taking global emission reduction goals $(25-40 \%)$ out of the negotiations of the pact to replace the Kyoto protocol. A KPMG survey of 70 Indian ceo's indicated that only one in five have measured their carbon emissions and $38 \%$ have no goals at all for reducing carbon emissions. The Indian government has stated, in their National Plan on Climate Change, a commitment that their per capita greenhouse gas emissions will "at no point exceed that of the developed countries," hardly a limit on their emissions when an average American is responsible for 20 times the greenhouse gas emissions as an average Indian. In fact, if the per capita emissions of China and India ever reached US levels, global emissions would be three times higher than today. India is, however, promoting the development of carbon sinks, in a project called "Green India", which is to be launched to preserve ecological balance and maintenance of biodiversity via reforestation of degraded forest land.

The difficulty in cutting emissions in a growing economy was shown in 2006 when China failed in its goal of reducing SO2 emissions by $10 \%$. The emissions actually grew by $1.8 \%$ in 2006 because of higher than expected economic growth.

China's government policy in the meantime has begun to boost energy efficiency, aiming to cut the amount of energy consumed per unit of GDP by $20 \%$ by 2010 . China's goal by 2020 is to generate $15 \%$ of their energy (up from 7\% in 2005) from renewable resources, backed up by investments of $\$ 10$ billion in 2007 (second only to Germany). Already China designed the 2008 Summer Olympics to be carbon neutral, achieved by the closure of enterprises, the use of solar power, tree planting, and restrictions on the use of cars, unfortunately mostly short-term measures.

In addition, both China and India are participating in the United Nation's Clean Development Mechanism Program whereby companies in rich countries get credits by sponsoring carbon cutting projects in poor countries. China is the largest beneficiary, receiving $\$ 5.4$ billion in 2007. India is the second largest beneficiary, receiving $\$ 445$ million that same year. Indeed, both countries will need to receive both funding and technology in order to achieve the major emissions reductions necessary.

Suggestions for specific programs that are needed in order to make major emission reductions include technological developments with regard to clean coal, as well as the diversification into and development of renewable energy resources such as solar, smaller hydroelectric, biomass and solar. More conservation is needed in the use of less water, energy and transportation. The two countries are being urged to safeguard the Himalayan glacier, better monitor the ecosystems, and initiate more sustainable habitats. Finally, with regard to the governments, suggestions include stronger government mandates and regulations, financial incentives for emissions reductions and penalties including fees, taxes and abatement costs, and removal of irrational subsidies that serve to increase emissions rather than reducing them. The Clean Development Mechanism needs to be expanded together with other international institutional funding policies.

Clearly the only real hope of containing global greenhouse gas emissions lies within the power of China and India to take the above steps and more; they are the largest total emitters and need to be a major part of the solution. The real key to getting them to participate will be to allow them to continue economic growth while simultaneously cutting back emissions, probably through the use of technology transfer and expanded financial 
support. Only with the participation of these two countries can the quantity of world-wide emission reduction be large enough to begin to stay the effects of global warming.

\section{SUMMARY}

China and India, already accounting for over $40 \%$ of the world's population, are also among the fastest growing economies of the world. That growth, however, comes with some cost. Pollution levels are high. Energy demands are increasing. And, China's release of greenhouse gasses is the largest in the world, with India's rapidly growing. The only real hope of curbing greenhouse gas emissions world-wide is for China and India to be a part of the global solution. And, the only way to achieve that is to find a way for them to continue their economic growth while simultaneously cutting back their total emissions.

\section{AUTHOR INFORMATION}

Dr. Betty Diener has been a Professor of Management at the Andreas School of Business at Barry University in Miam since 2002. Prior to that, she had been Professor of Marketing and Management in the College of Management at the University of Massachusetts in Boston until her retirement. In spring, 2001, Dr. Diener spent a semester as a Fulbright professor, lecturing on marketing and also on environmental management, at Tsinghua University's School of Economics and Management, in Beijing, China. She has recently received a Fulbright award to teach in India for December 2009 to April, 2010.

William Frank, Lecturer of Management. Mr. Frank worked for the IBM Corporation in several capacities including Regional Administration Support Manager, Program Manager in IBM World Trade. He joined Barry University's Andreas School of Business in 1999. While at Barry he has been the Coordinator of Undergraduate Advising, Coordinator of the ASB Freshman Orientation Program and the Assistant Dean for Students, and has now joined the faculty as a Lecturer of Management.

\section{REFERENCES}

1. CESifo Forum, "Recent Economic Growth and Challenges for China and India", Munchen: Spring 2007, Vol 8, Iss. 1- p.55-56

2. $\quad$ CESifo Forum, "Global Growth Prospects for 2008”, Munchen: Winter 2007, Vol 8, Iss.4, p.62

3. $\quad$ Chaturvedi, B., McClatchy-Business News, Newsweek, July 7, 2008

4. Clarke, Rory J., "The Impact of China and India in the Developing World", OECD Observer, Paris: Dec.2007/Jan.2008, Iss 264-265, p.13

5. Dougherty, S., "China and India - Making Sense of Innovation and Growth", OECD Observer, Paris: Dec.2007/Jan.2008, Iss 264-265, p.60-61

6. D'Sa, A., Murthy, K.V., "Environmental Reform in the Electric Sector: China and India”, Journal of Environment and Development, Vol. 15, No.2, June 2006, p.158-183

7. Economy, Elizabeth, "The River Runs Black: The Environmental Challenge to China's Future", Cornell University Press, 2004, pp19-20

8. EIU., "China/India Economy: Melting Asia", EIU Views Wire, New York: June 6, 2008

9. Inkpen, A., Ramaswamy, "End of the Multinational: Emerging Markets Redraw the World", The Journal of Business Strategy, Boston: 2007, Vol.28, Iss 5, pp4-12

10. International Energy Agency, "World Energy Outlook 2007: China and India Insights, Paris, 2007. ISBN: 9789264027305

11. Kaplinsky, F., "The Impact of China and India on the Developing World", CESifo Forum. Munchen: Spring, 2007, Vol 8, Iss 1, pp15-21

12. Koveos, P, Tang, L, "China and India: A Tale of Two Entrepreneurial Giants", Journal of Developmental Entrepreneurship, Norfolk: Dec. 2007, Vol 12, Iss.4, pp.377-381

13. Mayur, R. "India's Environmental Challenges", The Futurist, Washington: May/June 2001, Vol 35, Iss 3, p.10

14. "Melting Asia - China, India and Climate Change", The Economist, June 7, 2008, Vol.387, Iss.8583; p.30

15. Oster, S., Wall Street Edition, Eastern Edition, New York, Feb.13, 2007, p.A4 
16. "Prime Minister Unveils Climate Plan", McClatchy-Tribune Business News, Washington, July 1, 2008

17. Srinwasaran,T.N., Tendulkar, "Reintegrating India with the World Economy", Institute for International Economics, Washington, D.C. 2003

18. Wadhwa, K., McClatchy-Tribune Business News, Washington, July 24, 2005

19. Walsh, B, "Impact of Asia's Giants", Time, New York: April 3, 2006, Vol.167, Iss 14, pp.61-63

20. Wielard, R., and Max, A., "EU Hails Climate Deal as Example for World", The Arizona Republic, December 13, 2008, p.A6

21. Winning, D., “Asia Looks to Coal as Oil Prices Surge”, Wall Street Journal, New York: Jan. 4, 2008

\section{NOTES}

